\title{
Wind Tunnel Experiment on a Spherical Wind Vane
}

\author{
by
}

\author{
M. Sanuki, S. Kimura and M. Baba
}

University of Tokyo.

(Received April 25, 1962)

\begin{abstract}
A spherical wind vane is one of the conceivable two-directional wind direction measuring configurations due to its complete symmetry, and a linearized equation of motion is formed. The form is quite similar to that of the ordinary wind vane, of which some discussions and a wind tunnel test are given, too. The spherical wind vane is tested in the wind tunnel concerning its drag coefficient, and oscillation behaviour. The latter is compared with that of the ordinary wind vane, and found to possess peculiar and discouraging characteristics.
\end{abstract}

\section{Objective of the experiment}

In conjunction with the two-directional wind vanes which we experimented before (SanukI, Kimura and BABA, 1960) the possibility of a spherical wind vane was conceived. Such a vane can be said to be the resistance or drag type compared with the ordinary lift type utilizing a flat plate vane or an aerofoil. Our interest lies in difference, if any, in the wind-direction seeking behaviour in the wind.

\section{Lift type wind vane}

First the equation of motion of a lift type wind vane with moment of inertia $I$ will be discussed, which is given in the linearized form assuming a small amplitude

$$
\ddot{I}+c \dot{\theta}+c^{\prime} \theta=0 .
$$

Here $\theta$ denotes the amplitude of vane oscillation and the constants $c$ and $c^{\prime}$ are given by

$$
\begin{aligned}
& c=\frac{1}{2} C_{N \alpha} \rho S V R^{2}, \\
& c^{\prime}=\frac{1}{2} C_{N \alpha} \rho S V^{2} R,
\end{aligned}
$$

where $C_{N a}$ is the normal to vane chord air-force derivative with respect to the angle of attack in non-dimensional form, $\rho$ the air density, $S$ the vane surface area, $V$ the wind speed, and $R$ the arm length, i.e. the distance between the rotating axis and the vane aerodynamic center, or the point of action of air-force.

Equation (1) can be rewritten as 


$$
\ddot{0}+2 \zeta \omega_{n} \dot{\theta}+\omega_{n}^{2} 0=0
$$

where the damping ratio

$$
\zeta=\frac{c}{2 \sqrt{c^{\prime} I}},
$$

and the undamped natural frequency

$$
\omega_{n}=\sqrt{\frac{c^{\prime}}{I}} .
$$

The solution of Equation (1) is obtained for the initial conditions $\theta=\theta_{0}$ and $\dot{\theta}=0$ at $t=0$, as

$$
\theta=\frac{\theta_{0}}{\sqrt{1-\zeta^{2}}} e^{-\zeta \omega_{n} t} \cos \left[\sqrt{1-\zeta^{2}} \omega_{n} t-\varepsilon\right]^{*}
$$

where

$$
\tan \varepsilon=\frac{\zeta}{\sqrt{1-\zeta^{2}}} .
$$

The performed motion of the wind vane is a damped oscillation, the period of which is

$$
T=\frac{2 \pi}{\omega_{n} \sqrt{1-\zeta^{2}}}
$$

and the logarithmic damping is given by

$$
\Lambda=\frac{\pi \zeta}{\sqrt{1-\zeta^{2}}}
$$

From Equation (6) it can easily be shown that the time $\tau$ during which the envelope of oscillation amplitudes decays to $1 / e$ is equal to

$$
\tau=\frac{1}{\zeta \omega_{n}}=\frac{2 I}{c} \text {. }
$$

The writers termed $\tau$ the time constant, or better, the characteristic time, of oscillation.

$\tau$ is a figure of merit of the performed oscillation, because, as can be seen from Equation (9), smaller $\tau$ corresponds to larger $\zeta$ and $\omega_{n}$, and, in other words, smaller $T$ and larger $\Lambda$. Further, the constant $c$ is proportional to $S V R^{2}$ as shown in Equation (2), if other things are the same. As $S R^{2}$ is a measure of the system moment of inertia $I$ if the vane is constructed of the same material and same thickness, we can put

$$
\tau V \propto \frac{1}{\rho C_{N \alpha}}
$$

* $\zeta^{2}$ is usually small compared with unity and can be neglected. 
If the air density $\rho$ is of standard atmospsere, $\tau V$. is only influenced by $C_{N \alpha}$, which represents a purely aerodynamic and experimentally measurable figure.
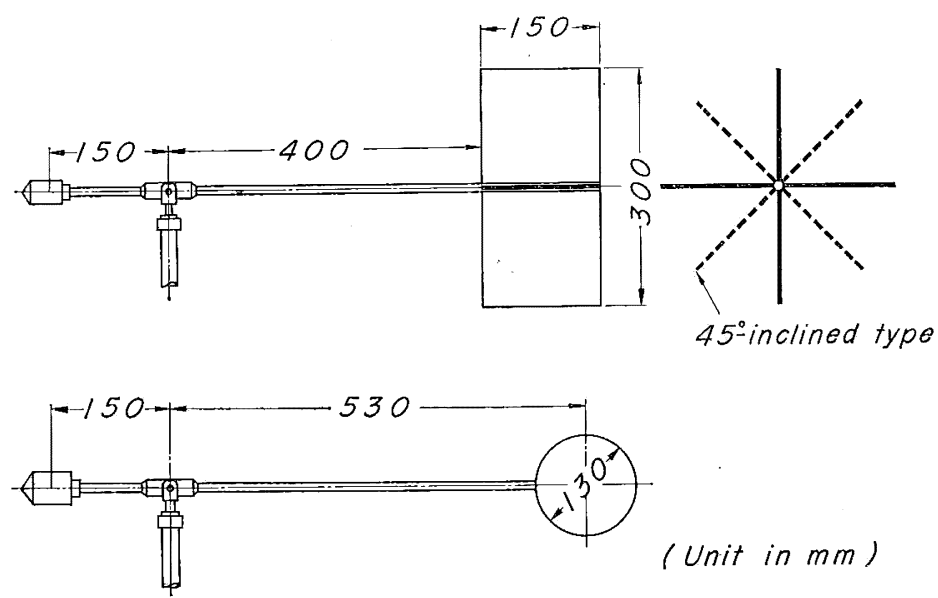

Fig. 1. Lift type wind vane (above) and drag type wind vane (below)

To obtain more realistic view we carried out a wind tunnel experiment of the vane configuration shown in Fig. 1 (above) to obtain $C_{N \alpha}$, which can be expressed as

$$
C_{N^{r} \alpha}=\frac{\partial C_{N}}{\partial \alpha}=\frac{\partial}{\partial \alpha}\left(C_{L} \cos \alpha+C_{D} \sin \alpha\right),
$$

where $\alpha$ stands for the angle attack, $C_{L}$ the lift coefficient and $C_{D}$ the drag coefficient. The experimental results for $C_{L}$ and $C_{D}$ are shown in Fig. 2 (left) against $\alpha . \quad C . P$. stands for the location of aerodynamic center between $L . E$. or leading (windward) and T.E. or trailing (leeward) edge of the vane.
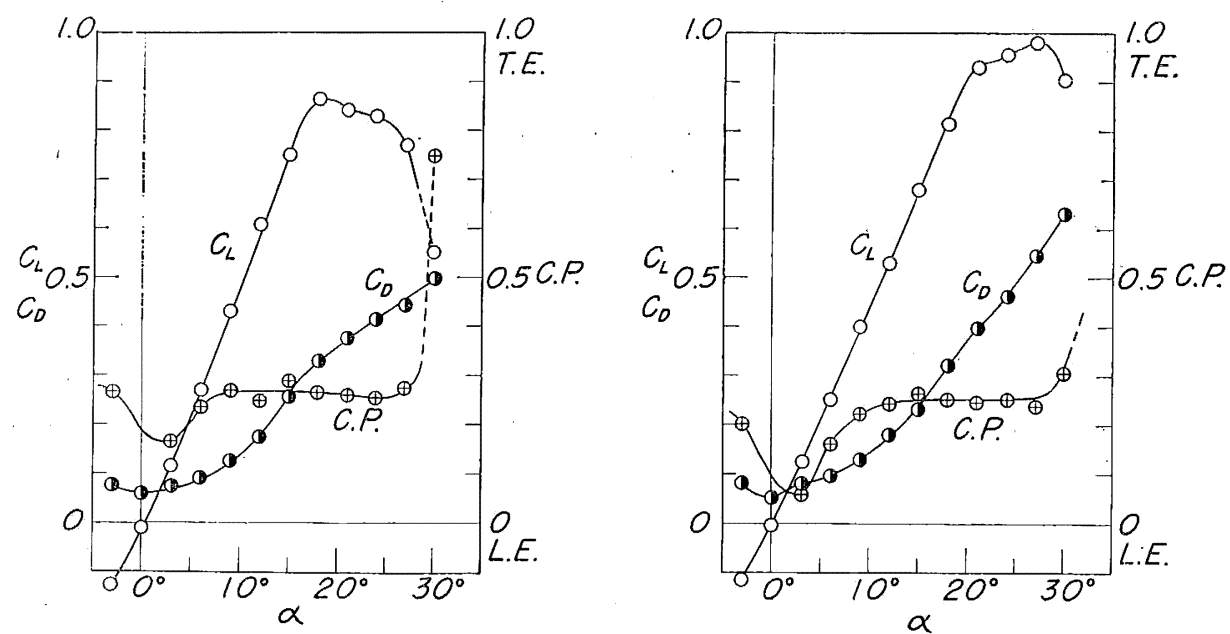

Fig. 2. Lift coefficient $C_{L}$, drag coefficient $C_{D}$, and aerodynamic center C.P. of equilateral cross (left) and $45^{\circ}$-inclined equilateral cross (right) wind vane. 
From these results $C_{N} \alpha$ can be estimated to be nearly 2.5 ( $\alpha$ is measured in radians) and $C . P$. nearly 0.25 times of the vane chord length from $L . E$., or, in actual scale, $150 \times 0.25=37.5 \mathrm{~mm}$, for the range of $\alpha=0^{\circ} \sim 10^{\circ}$, in which range the linearized Equation (1) is valid.

The results are put into (9) and we get

$$
\frac{\tau V}{I}=7.4 \mathrm{gr}^{-1} \mathrm{~s}^{-2} \text {. }
$$

In one of our preceding papers (SAnUKI, Kimura and Kato, 1957) we repotred on a series of experiment, from which the following result was obtained:

$$
\frac{\tau V}{I}=5.2 \mathrm{gr}^{-1} \mathrm{~s}^{-2}
$$

The discrepancy between the two results can be considered fairly small because the experiment (12) was extended largely into the non-linear region, i. e. well over $\alpha=30^{\circ}$ or more.

In Fig. 2 (right) the result for the same wind vane inclined $45^{\circ}$ around the horizontal supporting arm is shown, which gives nearly the same characteristics except for the delayed stall, i.e. a saturation or even a rapid drop of $C_{L}$. This delay is presumably caused by the $45^{\circ}$-inclination and is considered a favourable feature for a wind vane.

\section{Drag type wine vand}

The damping of a lift type wind vane is furnished by the variation of angle of attack caused by the rotational speed $R \dot{\theta}$, but for a pure drag type wind vane*, i.e. that utilizing a sphere as shown in Fig. 1 (bottom), the damping is due to the variation of effective arm length caused by the rotational speed. The linearized equation of motion can be established in just the same form as Equation (1), but the constants are now given as

$$
\left\{\begin{aligned}
c & =\frac{1}{2} C_{D} \rho S V R^{2}, \\
c^{\prime} & =\frac{1}{2} C_{D} \rho S V^{2} R,
\end{aligned}\right.
$$

where $C_{D}$ stands for the drag coefficient of sphere, $S=\frac{\pi}{4} D^{2}, D$ the sphere diameter, and $R$ is the distance between the rotating axis and the center of the sphere.

To obtain $C_{D}$ the set-up of Fig. 1 (bottom) is suspended in the $1.5 \mathrm{~m}$ wind tunnel of the Department of Aeronautics, University of Tokyo, and tested in the air flow ranging $5 \sim 30 \mathrm{~m} / \mathrm{s}$. The corresponding Reynolds number of the sphere ranges $0.6 \sim$ $2.5 \times 10^{5}$ and the value of $C_{D}$ is nearly constant as shown in Fig. 3. This is some-

* Two-directional. 
what odd and an excuse may be the turbulence caused by the supporting arm and its counterweight in the windward position.

This measurement is, so to say, statical, and the dynamical behaviour is experimented in the wind tunnel. The performed oscillation is quite peculiar in that the amplitude is damped as in the case of usual lift type wind vanes for the low wind speed of $V=3.5 \mathrm{~m} / \mathrm{s}$, but is poorly damped for larger wind speeds of $5 \mathrm{~m} / \mathrm{s}$ and $8 \mathrm{~m} / \mathrm{s}$, with a sustaining oscillation of amplitude of $10^{\circ} \sim 15^{\circ}$ after a transient.

The experimental determination

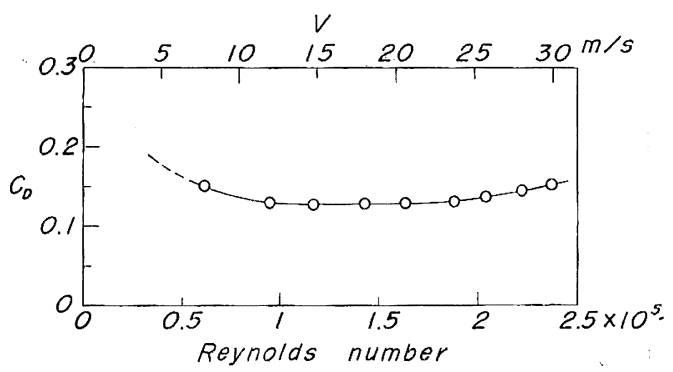

Fig. 3. Drag coefficient $C_{D}$ of sphere as attached to the wind vane ( $V=$ corresponding wind speed). of $T$ and $\tau$ is in itself very difficult or even impossible except for the low wind speed of $V=3.5 \mathrm{~m} / \mathrm{s}$, for which range the flow arround the sphere is laminar and $C_{D}$ is high affording a reasonable damping. For $V=3.5 \mathrm{~m} / \mathrm{s}$ the calculation of $T$ and $\tau$ based on $C_{D}=0.2$ and $I=4.29 \mathrm{grms}^{2}$ gives

$$
\frac{\tau V}{I}=4.4 \mathrm{gr}^{-1} \mathrm{~s}^{-2}
$$

whereas the oscillation test indicates

$$
\frac{\tau V}{I} \cong 6 \mathrm{gr}^{-1} \mathrm{~s}^{-2}
$$

which value shows a fair coincidence with the calculation. A Above $V=5 \mathrm{~m} / \mathrm{s}$, however, the flow arround the sphere seems very turbulent and unsteady affording extremely poor damping, or rather, the flow supplies energy causing the oscillation to continue.

The calculated $\tau$ based on $C_{D}=0.15$ is

$$
\frac{\tau V}{I}=6.3 \mathrm{gr}^{-1} \mathrm{~s}^{-2},
$$

whereas the oscillation test affords a wide variety of

$$
\frac{\tau V}{I}=10 \sim 20 \mathrm{gr}^{-1} \mathrm{~s}^{-2}
$$

At this stage of knowledge, we can only put forward a conjecture that, referring to Equations (9) and (14), a strong reduction, say, down to one third of the statical value, in $C_{D}$ of the sphere might happen in this range of test.

On the whole, a spherical wind vane seems an awkward choice owing to its poor and doubtful damping. 


\title{
4. Conclusions
}

1) If the air-force derivative of a lift type wind vane is known, the prediction of vane oscillation mode can be done fairly accurately.

2) Even if the drag coefficient of the spherical wind vane is known, its actual dynamical behaviour is quite peculiar and hard to predict. Its use is doubtful.

3) The dynamical behaviour of a sphere in the wind is of further interest.

Acknowledgement___ In the wind tunnel test assistance was extended by Messrs. I. Arai and M. Matsuzaka of our Department of Aeronautics, to whom the writers are much obliged.

\section{References}

Sanuki, M., S. Kimura and M. Baba, 1960: Wind tunnel experiment on two-directional wind vanes, Pap. Met. Geophys. 11, pp. 23-29.

SanUk1, M., S. KinuRA, and H. Kato, 1957: Time constant of a monoplane wind vane of which the moment of inertia and arm length are systematically changed, Pap. Met. Geophys. 8, pp. 232-235.

\section{球形風向計 の風洞 実 験}

\author{
佐貫亦男，木村 茂，馬場素生
}

2 方向風向訃の問題飞関连して，球を使うことの提案があつたので東京大学の $1.5 \mathrm{~m}$ 風悯で実験してみ た。ところが振動の減衰が $3.5 \mathrm{~m} / \mathrm{s}$ 以下の風速では, 通常の風向計飞くらべてはなはだしく覀くないが $5 \sim 8 \mathrm{~m} / \mathrm{s}$ では極端飞恶いことがわかつた。もう一つの欠点は各風速を通じて真風向と落ちつかず，竹侧 $10^{\circ}$ 程度の残留振幅がいつまでも続くことである。別の風润実跧で求めた球の抵抗係数を使つて，振動垁

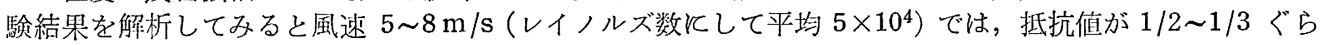
い低下していることになる。いずれとしても，球形風向計は思わしくない形式である。な物本文飞は，通 常の風向計の空気力学的ならびそ振動特性をまとめてある。 